\title{
Extracellular vesicles: potential roles in regenerative medicine
}

\author{
Olivier G. De Jong ${ }^{1}$, Bas W. M. Van Balkom ${ }^{1,2 *}$, Raymond M. Schiffelers ${ }^{3}$, Carlijn V. C. Bouten ${ }^{2}$ and \\ Marianne C. Verhaar ${ }^{1}$
}

${ }^{1}$ Department of Nephrology and Hypertension, University Medical Center Utrecht, Utrecht, Netherlands

2 Department of Biomedical Engineering, Eindhoven University of Technology, Eindhoven, Netherlands

${ }^{3}$ Department of Clinical Chemistry and Hematology, University Medical Center Utrecht, Utrecht, Netherlands

Edited by:

Marcella Franquesa, Erasmus

Medisch Centrum, Netherlands

Reviewed by:

Rae Ritchie, Bioscience Vaccines Inc., USA

Miroslaw Kornek, University of

Saarland, Germany

*Correspondence:

Bas W. M. Van Balkom, Department

of Nephrology and Hypertension,

UMC Utrecht, Heidelberglaan 100,

G.02.402, Utrecht 3584 CX,

Netherlands

e-mail:b.w.m.vanbalkom@

umcutrecht.nl
Extracellular vesicles (EV) consist of exosomes, which are released upon fusion of the multivesicular body with the cell membrane, and microvesicles, which are released directly from the cell membrane. EV can mediate cell-cell communication and are involved in many processes, including immune signaling, angiogenesis, stress response, senescence, proliferation, and cell differentiation. The vast amount of processes that EV are involved in and the versatility of manner in which they can influence the behavior of recipient cells make EV an interesting source for both therapeutic and diagnostic applications. Successes in the fields of tumor biology and immunology sparked the exploration of the potential of $\mathrm{EV}$ in the field of regenerative medicine. Indeed, EV are involved in restoring tissue and organ damage, and may partially explain the paracrine effects observed in stem cell-based therapeutic approaches. The function and content of EV may also harbor information that can be used in tissue engineering, in which paracrine signaling is employed to modulate cell recruitment, differentiation, and proliferation. In this review, we discuss the function and role of EV in regenerative medicine and elaborate on potential applications in tissue engineering.

Keywords: regenerative medicine, tissue engineering, extracellular vesicles, exosomes, microvesicles

\section{INTRODUCTION}

Regenerative medicine aims at the functional restoration of a damaged, malfunctioning, or missing tissue. There are three main approaches in regenerative medicine. The first approach is cellbased therapies, where cells are administered to restore a tissue either directly or through paracrine functions. The second approach is often referred to as classical tissue engineering, and consists of the combined use of cells and a bio-degradable scaffold to form a tissue. Lastly, much progress has been made in materialbased approaches, which rely on bio-degradable materials, often functionalized with cellular functions.

The first development in replacing malfunctioning tissues was by transplanting organs, tissues, or cells. Over the course of the last century vast improvements were made in the field of transplantation, starting with bone and cornea transplants at the beginning of the twentieth century, followed by the first kidney transplantation in the 1950s (1-3). As transplantation techniques for other organs developed over the following decades, the limiting factor for these procedures shifted from technical limitations to the supply of suitable organs and tissues. Besides shortage in supply, organ and tissue transplantation have another major drawback: the risk of immune rejection and the required chronic immunosuppression treatment.

In response to these issues, research focused on strategies that allow functional restoration of damaged tissues by cellfree approaches or approaches using autologous cell and tissue sources. Embracing the rapid developments in technology and our understanding of biological processes, the field of regenerative medicine is focusing on a wide array of techniques and approaches to restore tissue function. Suitable approaches depend on the function and environment of the newly generated tissue. For instance, in the replacement of insulin-producing cells in patients with type-1 diabetes, there is little need for load-bearing structures, but rather for structures mimicking the extracellular matrix (ECM) like hydrogels, to retain and stimulate insulinproducing cells (4). Heart valve replacements on the other hand require materials that are able to withstand large forces in addition to high flexibility (5), but due to their direct contact with a patients' circulation also require the use of materials with high hemocompatibility and low immunogenicity. Utilizing autologous stem-, progenitor-, and tissue-specific cells to restore damaged tissues may bypass the problem of immunogenic responses against these implants. Following recent insights that the structural contribution of stem cells to regenerated tissues is limited, and that rather the stimulation of local healing processes plays an important role (6-9), research has increasingly focused on the paracrine hypothesis, investigating the stimulating factors released by these stem- and progenitor cells, including growth factors, cytokines, and extracellular vesicles (EV). At the same time, major breakthroughs in the field of EV have uncovered roles for EV in many processes including angiogenesis, regulation of immune responses, and ECM remodeling (10-13), which may be of specific interest for tissue engineering. Here, we review the recent developments in regenerative medicine and EV research, and discuss potential 
therapeutic applications of $\mathrm{EV}$ in restoring function in damaged tissues.

\section{REGENERATIVE MEDICINE: CELL THERAPIES}

One of the earliest applications of cell therapy was the administration of cells for the reconstitution of blood or bone marrow (14, 15). As a result of developments during the last decades, including improved techniques in both transient and permanent regulation of gene expression, methods of cell isolation and propagation, and improved protocols to regulate differentiation of cells, cell therapies currently play a prominent role in the field of regenerative medicine (16). Cell therapies can directly aid repair by forming new functional tissues, or support tissue repair through paracrine mechanisms, for instance by secreting growth factors, immunomodulatory molecules, and EV. Examples of direct tissue formation by cell therapy are the use of autologous epithelial cells to repair cornea injuries (17), expansion, and transplantation of chondrocytes in cartilage repair (18), or the administration of endothelial colony-forming cells (ECFC) in a murine hind limb ischemia model to increase neovascularization (19). In these studies cell populations were isolated, expanded ex vivo, and re-introduced at the site of injury to generate new, functional tissues. The ex vivo expansion step allows the use of only limited amounts of tissue and the proper characterization of isolated cells. Adverse effects as dedifferentiation and induction of senescence are great challenges adhered to this approach (20). For instance, in vitro passaging of mesenchymal stem cells (MSC) results in cell enlargement, differentiation, and decrease in proliferation within 10 passages (21), and causes a strong response to microenvironment stiffness, affecting cell morphology, and function (22). Progenitor cells from aged or diseased donors show decreased proliferation, prevalence, as well as functionality (23-25). Despite these challenges, promising results have been achieved, for instance in treatment of patients with severe autoimmune diseases with hematopoetic stem cell transplantation (26).

It has become increasingly apparent that a more supporting role, employed by secretion products of stem and progenitor cells is responsible for many of the observed effects of stem cell therapies (6-9). These paracrine factors secreted by stem- and progenitor cells, like growth factors and cytokines, are of major interest to discover new therapeutics that stimulate local tissue regeneration for the use in tissue engineering as well [reviewed in Ref. $(27,28)]$.

\section{TISSUE-ENGINEERING: (BIO-)ENGINEERED SUPPORT}

Repair of damaged tissue requires not only the presence of cells capable of restoring the damaged structure, but requires a microenvironment that promotes appropriate tissue regeneration as well. In addition, cells need to be guided to form a structure of the appropriate size and shape, and in many cases (for instance in bone or cartilage repair, as well as in cardiovascular substitutes), require structural support. In a healthy tissue, the ECM plays a key role in guiding and regulating these processes, whereas in damaged tissue, the ECM is often absent, damaged, or functionally impaired. To address this problem and allow in situ regeneration, structures that (temporarily) provide the requirements for cell retention and tissue regeneration are employed and are referred to as scaffolds.
Scaffolds can either be of natural origin, such as decellularized ECM or modified elastin- or collagen gels, or of synthetic origin, such as synthetic hydrogels or porous polymer scaffolds. Using decellularized ECM from xenogenic or allogenic donors provides scaffolds that are most similar to the natural extracellular environment. Use of decellularized matrices is a promising technique, which yields biocompatible scaffolds with appropriate physical and biological properties. Many ECM components, as well as growth factors, are often conserved and can aid in proper regeneration of functional tissues (29). To decrease the risk of immune responses against antigens in these scaffolds, as well as the potential transfer of pathogens, a combination of enzymatic, physical, and chemical treatments is used to remove cellular components from the tissue (29). Decellularized matrices have been used for tissue engineering of several tissues, including heart valves (30), vascular grafts (31), and trachea (32). However, use of decellularized matrices has several disadvantages. Acquiring and isolating of appropriate tissues, followed by decellularization protocols, can be a relatively time-consuming and expensive procedure, and incomplete decellularization or antigen removal can result in immune reactions against grafts (33). Cell seeding of decellularized matrices can be technically challenging due to structural dimensions and porosity. Furthermore, control over the exact content of the matrices is limited due to donor variation, and despite pretreatment still there exists the risk of transfer of pathogens. In order to create scaffolds in a safe, reproducible, affordable, and controlled manner, extensive research is ongoing on the production of artificial porous scaffolds, exploring various production techniques and materials (34).

Artificial porous scaffolds should meet specific requirements to allow homing of appropriate cell populations. Ideally, a synthetic scaffold temporarily provides the required support and micro-environment, is bio-degradable and eventually replaced by autologous ECM. For cells to be able to migrate or be seeded in the scaffold and allow an environment with proper supply of nutrients, a porous structure is required (35). There are several techniques to generate porous scaffolds, including solvent casting, forming emulsions before polymerization, gas foaming, as well as binding of polymeric fibers by chemical treatment or heating (36-39). Using these techniques in generating scaffolds with consistent porosity in complex shapes, containing areas of varying thickness and materials, is technically challenging. Currently, the most commonly used technique in generating porous synthetic scaffold is electrospinning, which allows the generation of constructs with complex geometry, consisting of combinations of fiber types in both mixed and layered patterns (40). Bio-degradable polymers used in electrospinning include poly( $\varepsilon$-caprolactone) (PCL), poly (glycolic acid) (PGA), poly (hydroxy alkanoate) (PHA), and poly(lactic acid) (PLA). Mixing fiber types in specific patterns allows modulation of degradability, strength, and biological activity of scaffolds (41).

Electrospun scaffolds can be pre-seeded with autologous cells, which may be re-programmed, differentiated, and expanded in vitro, and can then be directly implanted or incubated in a bioreactor until the electrospun meshwork is fully degraded and replaced with ECM (5). Alternatively, scaffolds can be implanted 

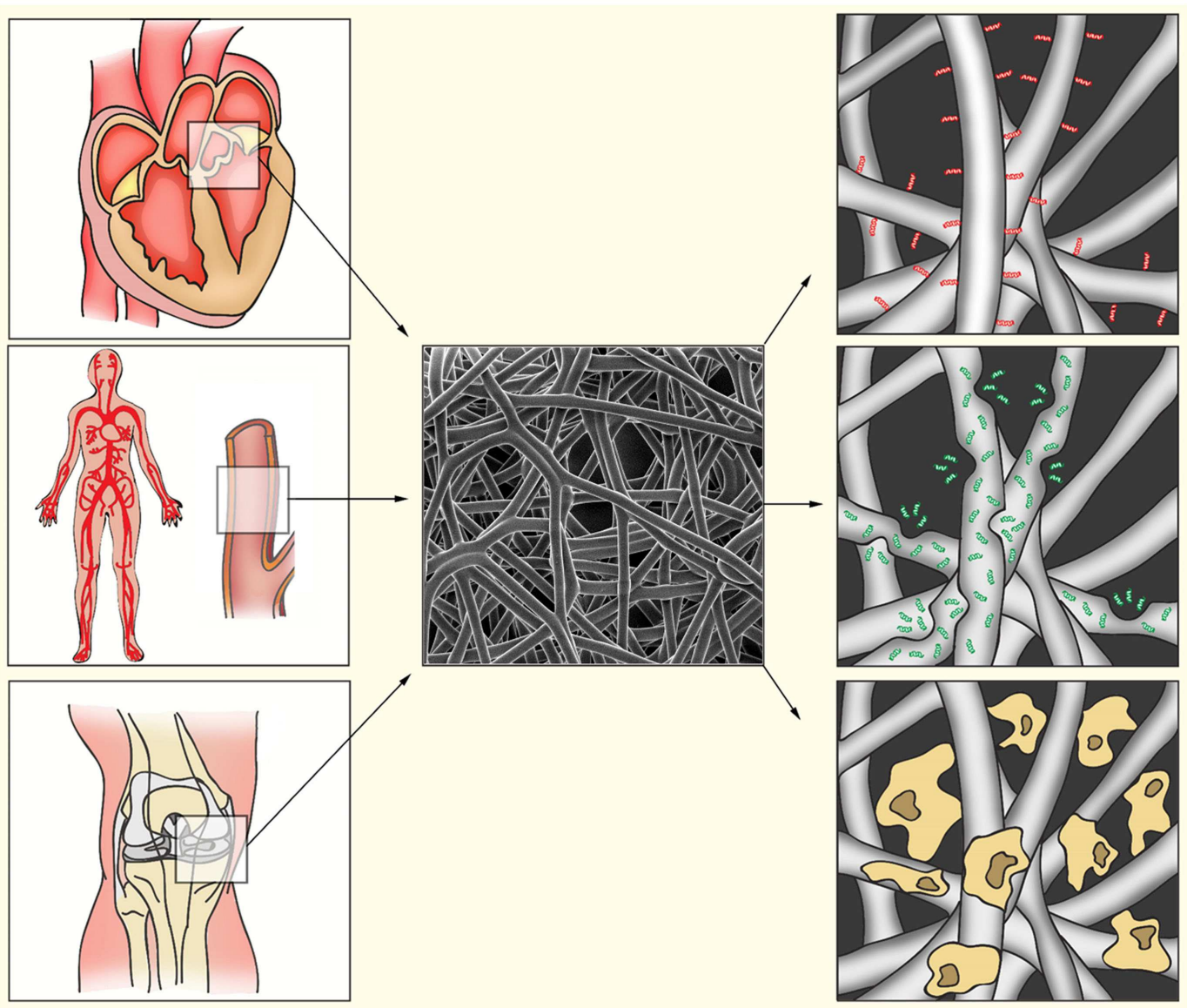

FIGURE 1 | Bio-activated artificial scaffolds. Electrospinning allows formation of constructs with a variety in shapes, sizes, and tissue strength. This allows the production of constructs for a variety of tissues (left). Electrospun fibers (middle) can be bio-activated by coating of the fibers with proteins or peptides (right, red).
Incorporation of bio-active components into the fibers will result in gradual release during fiber degradation (right, green). After electrospinning, fibers can also be pre-seeded with appropriate cell populations to induce ECM production, angiogenesis, or immunomodulation (right, yellow). without pre-seeding, allowing in situ recruitment of autologous cells and circumventing the expensive, time-consuming, and challenging process of cell isolation and expansion in vitro. Incorporation of bio-active molecules into the scaffold may be used to recruit proper cell populations, modulate the immune response, or guide cells to differentiate (Figure 1). For instance, ECM-derived peptides like the integrin recognition site peptide Arg-Gly-Asp (RGD) enhance cell adhesion and cell viability in scaffolds $(42,43)$, whereas coating with type I collagen-mimetic peptide enhances the migration, proliferation, and osteogenic differentiation of MSC (44). Scaffolds can also be designed to release peptides, proteins, or cytokines during degradation, or by coating fibers with a mixture of these bio-active molecules in a bio-degradable substance like fibrin or gelatin. For example, gradual release of vascular endothelial growth factor (VEGF) - a hypoxia-regulated growth factor that plays a key role in angiogenesis - and plateletderived growth factor (PDGF) promoted endothelialization and smooth muscle cell ingrowth in electrospun scaffolds (45). Release of stromal cell-derived factor (SDF)- $1 \alpha-a$ chemokine that is up-regulated in tissue damage and hypoxia, attracts hematopoietic stem cells, and induces endothelial progenitor cell (EPC) recruitment - by electrospun poly(lactic-co-glycolic acid) (PLGA) scaffolds reduced mast cell degranulation, and increased angiogenesis and decreased fibrosis (46). Coating of interposition grafts with SDF- $1 \alpha$ combined with the ECM component fibronectin (47), or treatment with VEGF (48) has been reported to enhance graft endothelialization.

Many of the bio-active compounds used in these approaches act as paracrine factors in natural healing processes, or on the secretome of stem- or progenitor cell populations that induce local tissue regeneration in vivo (27). EV constitute a part of the secretome that also play an important role in local induction of tissue regeneration. For example, cardioprotective effects of conditioned medium from MSC in ischemia/reperfusion injury were shown to be mainly mediated by EV (49). Given the previous successes of paracrine factors in tissue engineering, these mediators of intercellular communication could also be of interest in the field of regenerative medicine. 


\section{EXTRACELLULAR VESICLE CHARACTERISTICS}

Extracellular vesicles are lipid membrane vesicles, containing a variety of RNA species (including mRNAs, miRNAs), soluble (cytosolic) proteins, and transmembrane proteins presented in the appropriate, and functional orientation (50-52). EV play a role in many processes, including intercellular communication, recycling of membrane proteins and lipids, immune modulation, senescence, angiogenesis, and cellular proliferation and differentiation $(10,13,52-56)$. Cells release several types of vesicles with different physiological properties, content, and function, as a result of their different mechanisms of generation, and include exosomes, microvesicles, and apoptotic bodies (57). In the EV research community, a full consensus in terminology and classification of vesicles is yet to be achieved (58). In the past, vesicle nomenclature was mainly based on the tissue of their origin. More recently, the field has started to shift toward a terminology that focuses rather on the mechanisms of generation of these vesicles. Vesicles in the first category, exosomes, originate in multivesicular bodies (MVB) (Figure 2, left). When MVB fuse with the plasma membrane, the intraluminal vesicles are released from the cell and are from thereon referred to as exosomes. Exosomes are reported to be between 40 and $150 \mathrm{~nm}$ in size, with a density ranging from 1.09 to $1.18 \mathrm{~g} / \mathrm{ml}$. The most common markers used are tetraspanins such as CD9, CD63, CD81, and CD82, lipid raft markers Flotillin1 and -2, as well as Alix and Tsg101. Other markers that are used are heat shock proteins, MHC molecules, various components of the ESCRT complex and proteins of the Rab protein family (50, 51,59-61). Microvesicles are shed directly from the plasma membrane and can be a lot larger than exosomes $(50-1000 \mathrm{~nm})(62)$. There is, however, an overlap in size between these two populations. Microvesicles also contain mRNAs and miRNAs, as well as soluble and transmembrane proteins. Like exosomes, microvesicles are able to transfer functional genomic and proteomic content to target cells $(63,64)$. Apoptotic bodies originate at the cell membrane as cells undergo apoptosis. Even though these vesicles are of interest in biomarker research, and have been shown to have effects on other cells, research on these vesicles in intercellular communication is limited (65-67). Furthermore, vesicular cell-derived microparticles with biological functions have been described (68-70). However, most descriptions of microparticles are heterogeneous with regard to the isolated biomaterials or refer to characteristics of non-cell-derived compounds, and depending on the protocols used these microparticles may contain exosomes, microvesicles, apoptotic bodies, or varying combinations of these vesicle populations. Generally, the term EV is used when discussing exosomes or microvesicles, or a combination of these vesicle populations, depending on isolation techniques. However, due to the technical limitations of current isolation techniques, samples may occasionally also contain apoptotic bodies and protein aggregates.

The first report of a cellular function of exosomes was the shedding of the transferrin receptor by maturing reticulocytes $(55,71)$. Pan and Johnstone showed that removal of this receptor from the

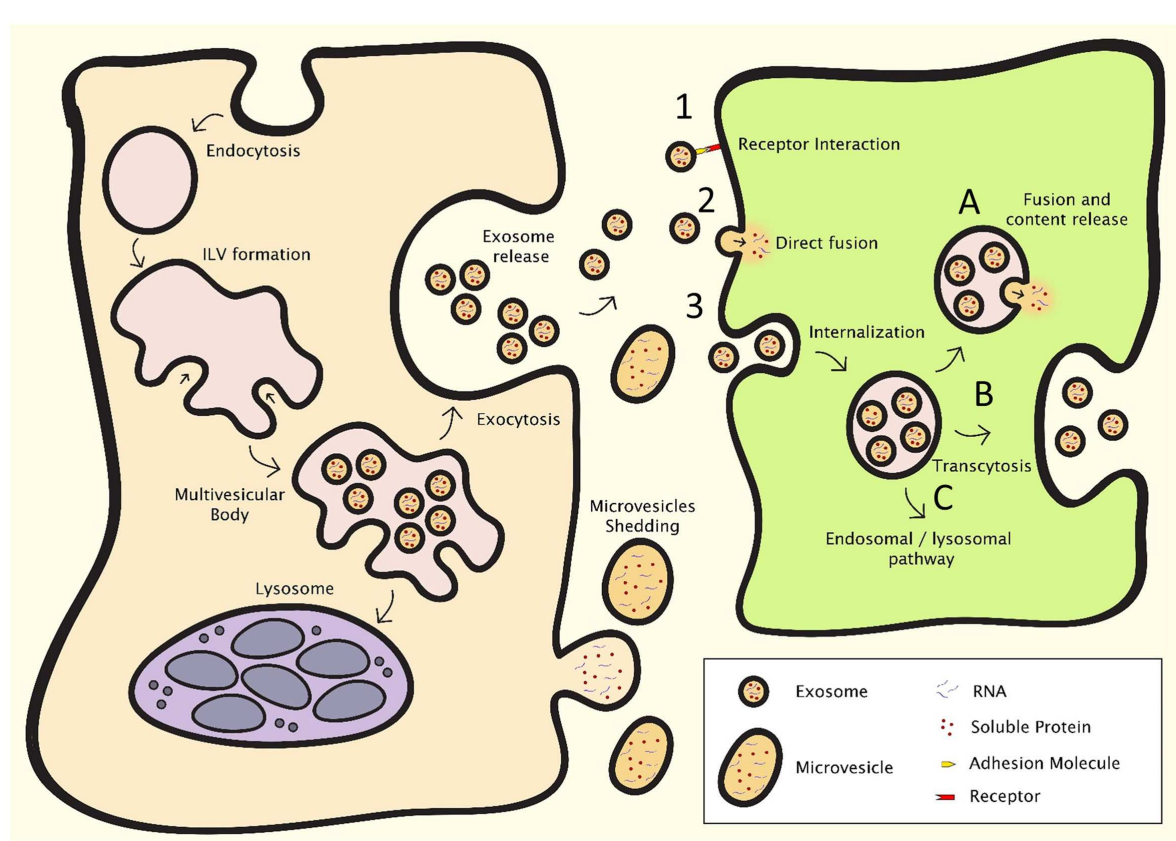

FIGURE 2 | EV formation (left) and intercellular communication (right). After endocytosis, intraluminal vesicle formation occurs in the late endosome, resulting in the formation of the multivesicular body (MVB). The MVB can either fuse with the lysosome, resulting in breakdown and recycling of its contents, or fuse with the plasma membrane, resulting in the release of the intraluminal vesicles, which are then deemed exosomes. Microvesicles shed directly from the plasma membrane. Intercellular communication can occur through three major processes: (1) direct interaction of ligands expressed on the surface of EV with receptors on the cell membrane, (2) direct fusion of the EV with the cell membrane, resulting in the release of the content of the $\mathrm{EV}$, or (3) internalization through the endocytotic pathway, which can result in $(A)$ fusion of the $E V$ with membrane of the endosome, resulting in content release, (B) transcytosis, or (C) degradation through the lysosomal pathway. 


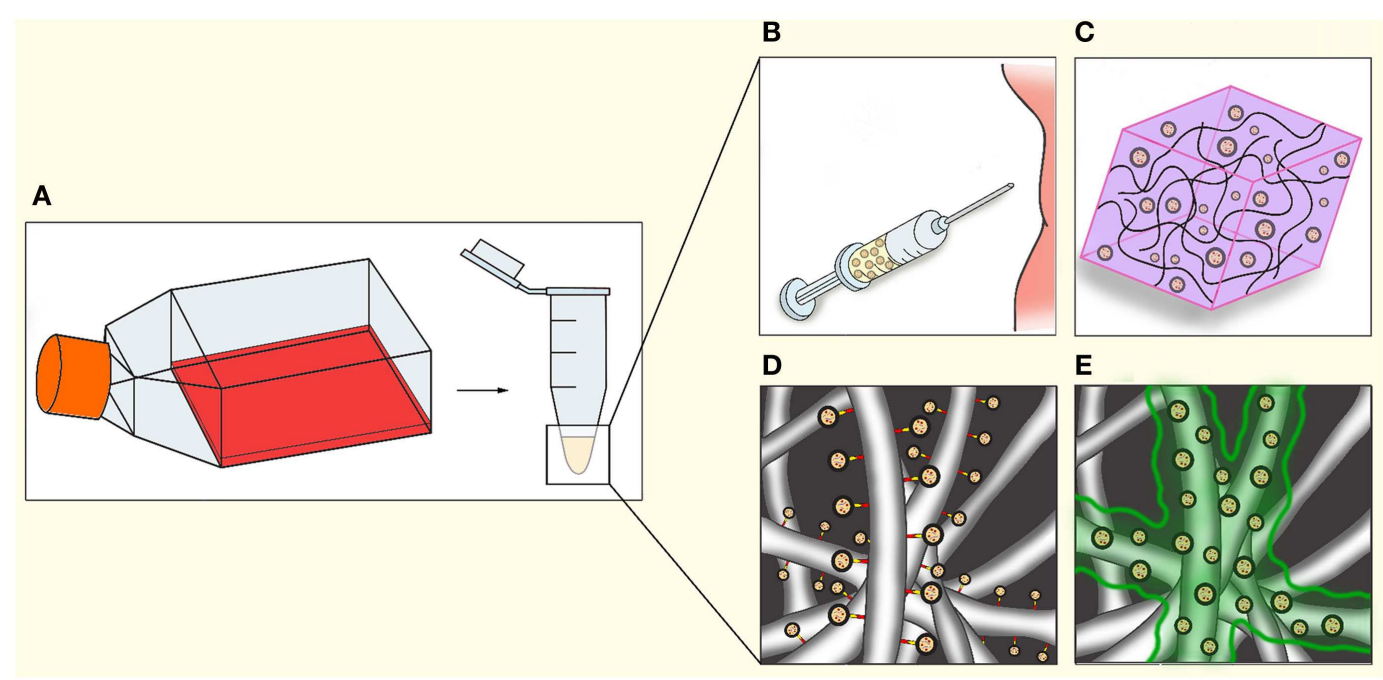

FIGURE 3 | Applications of EV in regenerative medicine. After isolation (A), EV could be utilized in regenerative medicine through a number of methods, either separately or in combination with cells or other therapeutics. (B) Direct injection into tissue or circulation. (C) Mixing of EV in hydrogels. (D) Coating electrospun fibers indirectly via chemical linkers, antibodies, or specific tags engineered on to the EV. (E) Coating of electrospun fibers with bio-degradable gels such as fibrin, resulting in gradual release during gel degradation. cell membrane occurred through endocytosis, followed by formation of intraluminal vesicles (forming the MVB), which were released when the MVB fused with the cell membrane. After this discovery, it was believed that the exosome pathway was mainly involved in cell homeostasis, by secreting cellular waste (72). Not until a study of Raposo et al. for the first time showed an immunological role for exosomes, the stimulation of $\mathrm{CD}^{+}{ }^{+} \mathrm{T}$ cells by EBV-transformed B-cells in an antigen specific manner, did researchers begin to explore additional functions (12). Primarily being studied in the context of immunology, exosomes were increasingly considered potential mediators for intercellular communication. However, it was only after the discovery that exosomes are able to transfer functional mRNAs and miRNAs from one cell to another, that the field gained its full momentum (52, 73). Microvesicles have also been reported to transfer functional mRNAs and miRNAs to cells $(66,67)$.

Extracellular vesicles can communicate with target cells through several mechanisms (Figure 2, right). Firstly, transmembrane proteins on the EV membrane can interact with receptors on the cell membrane. These receptor-ligand interactions can then activate signaling cascades to affect target cells. EV can also fuse with their target cells to release their cargo, either by direct fusion with the cell membrane or by endocytosis, after which mRNAs, miRNAs, and proteins are released into the cytosol. Fusion of EV with target cells can either occur directly at cell membrane, or after endocytosis. After fusion, mRNAs transferred by EVs can be translated in to protein, and delivered miRNAs inhibit mRNA translation and affect cellular processes. The cargo and function of EV depends on their producing cells, and it has been shown that also cellular stress affects EV content, suggesting that intercellular communication through EV is a dynamic system, adapting its "message" depending on the condition of the producing cells (50-52, 74).

\section{EXTRACELLULAR VESICLES IN REGENERATIVE MEDICINE}

Extracellular vesicles are able to affect cell phenotype, recruitment, proliferation, and differentiation in a paracrine manner. These paracrine effects of $\mathrm{EV}$ have a potential benefit in regenerative medicine. EV can be incorporated in regenerative therapies, for example by (co-)injection, mixing with hydrogels, or coating scaffolds with EV using fibrin gels or specific linkers (Figure 3). Here, we will discuss the role of EV in essential processes in regenerative medicine: cell viability, immune responses, ECM interaction, and angiogenesis.

\section{CELL SENESCENCE, VIABILITY, AND PROLIFERATION}

Prevention of cell death and cell senescence is vital in optimizing efficiency of regenerative medicine, both in cell therapies as well as in tissue engineering (75). Cell senescence depends on both the cell source and the environment to which cells will be introduced. Bone marrow-derived MSC from aged donors show increased senescence, and decreased proliferative potential (76, 77), and uremic toxins promote cell senescence (78). Pretreatment of progenitor cells such as MSC affects cell senescence as well. For example, long-term in vitro expansion of MSC induces senescence, and reduces differentiation potential $(79,80)$.

Extracellular vesicles may affect cell senescence, proliferation, and cell survival. We recently demonstrated that endothelial cell-derived exosomes induced angiogenesis by inhibition of cellular senescence, and that transfer of miR-214 downregulated ataxia telangiectasia mutated (ATM) expression in recipient cells, resulting in decreased cellular senescence (13). Human umbilical cord MSC-derived microvesicle treatment suppressed cisplatin-induced apoptosis, and resulted in increased cell proliferation through regulation of the ERK $1 / 2$ and MAPK pathways, both in vitro and in vivo (81). EV derived from human cardiac progenitor cells contain anti-apoptotic miRNAs, miR-210 and 
miR-132, and treatment with these EV in a myocardial infarction resulted in decreased cardiomyocyte apoptosis (82). Similarly, bone marrow MSC-derived exosomes were able to decrease apoptosis and increase cell proliferation in an acute kidney injury model, and the authors hypothesized that this was the result of exosome-mediated RNA transfer (83). Similar results were obtained by Bruno et al., who showed that administration of MSC-derived microvesicles decreased apoptosis in an acute kidney injury model and in vitro in cisplatin treated human epithelial cells, through up-regulation of anti-apoptotic genes and downregulation of several apoptotic genes (84). Further in vitro studies showed that cardiomyocyte protection by MSC is partially mediated by transfer of miR-221 in microvesicles, resulting in reduced caspase activity after ischemic injury (85). Certain EV have also been shown to increase cell proliferation. Tumor-derived EV were reported to induce proliferation in a variety of tissues (86-88). MSC-derived EV have also been found to increase proliferation: bone marrow MSC-derived exosomes induced proximal tubular epithelial cell proliferation in an acute kidney injury model (89), and umbilical cord MSC-derived exosomes increased in vitro skin cell proliferation as well as migration after heat-stress, through Wnt signaling by trafficking of Wnt4 (90). Interestingly, Zhang et al. also observed that treatment with these vesicles in a rat skin burn model resulted in accelerated epithelialization (90). Exosomes derived from tubular epithelial cells stimulated with hypoxia activated fibroblasts through TGF- $\beta 1$ signaling, resulting in increased fibroblast proliferation, which could aid in acceleration of tissue repair (91). These studies indicate that EV play a role in local tissue repair through regulation of cell proliferation.

The capacity of EV to regulate cell senescence, apoptosis, and proliferation, parameters that greatly affect tissue engineering and cell therapy outcome, suggest therapeutic potential in regenerative medicine. Indeed, MSC-derived vesicles show positive effects on tissue repair through various pathways, even reducing apoptosis as a result of ischemic injury (92). This is of interest, since ischemia in larger tissue-engineered constructs is a substantial issue (93).

\section{ANGIOGENESIS}

Tissue engineering of large tissues requires proper vascularization for sufficient supply of nutrients and oxygen, and draining of cellular waste. Since tissue-engineered constructs thicker than $100-200 \mu \mathrm{m}$ already run in to problems in respect to oxygenation, nutrient supply, and removal of waste products, controlled vascularization of neo-tissue is vital (93). Strategies to induce vascularization include addition of endothelial (progenitor) cells, engineering vasculature, as well as the use of paracrine factors (93-95). Several studies on cancer-derived EV demonstrated their role in tumor angiogenesis through a variety of pathways, including cell cycle-related mRNAs, several major intracellular kinase pathways, transfer of miRNAs, and by carrying pro-angiogenic cytokines (96-100). EV from endothelial cells have also been demonstrated to induce an angiogenic program in target endothelial cells in vitro and in vivo both through Notch-dependent tip-cell formation and induction of a pro-angiogenic program in parallel to miR-214-dependent repression of senescence $(13,101)$. EV from other cell types have been demonstrated to stimulate in vitro and in vivo vessel formation by endothelial cells as well.
For example, adipose MSC-derived EV, which could be increased in function and number by PDGF stimulation (102), as well as bone marrow MSC-derived EV, promoted angiogenesis in a rat myocardial infarction model (103). In the latter model, hypoxic stimulation of the EV-producing cells was required to obtain functional EV. Similar effects of hypoxia were observed in microvesicles from human umbilical cord MSC, which promote angiogenesis in vitro as well as in vivo in a rat hindlimb ischemia model (103, 104). These findings underline the importance of culturing conditions of their producing cells on EV content (74). Cantaluppi et al. showed that EPC-derived microvesicles increase endothelial cell proliferation, migration, and vessel formation in vitro by transfer of pro-angiogenic miRNAs, miR-126 and miR-296. These EPC microvesicles also increased vascularization of islet endothelium and $\beta$-cells transplanted in SCID mice (105) and, in a SCID mouse hind limb ischemia model increased capillary density, enhanced limb perfusion, and reduced injury after 7 days (106). A study by Sahoo et al. in 2011 showed that exosomes isolated from $\mathrm{CD}_{3}{ }^{+}$mononuclear cells increased endothelial cell viability, proliferation and tube formation in vitro, and stimulated angiogenesis in vivo in both matrigel plug- and corneal assays, and that the pro-angiogenic effect of these cells was mainly through these EV (107).

Overall, different types of EV appear to be able to induce angiogenesis through a variety of pathways, and through transfer of mRNA, miRNAs, and proteins, underlining their potential in tissue engineering.

\section{EXTRACELLULAR MATRIX INTERACTIONS}

The ECM plays a major role in tissue engineering, providing shape and strength to the newly formed tissue as well as a site for interactions with and guidance of cells. Both ECM architecture and molecular composition are determinants for cell recruitment, retention, and differentiation, and thus the final local cell phenotype. In tissue engineering strategies using bio-degradable scaffolds, the load-bearing and cell retaining function of the scaffold will have to be fulfilled by the locally produced ECM after the scaffold is degraded. EV are able to influence ECM composition through direct ECM interactions, or by interacting with ECM-producing cells.

Extracellular vesicles express adhesion molecules, including members of the immunoglobin superfamily and integrins. Exosomes derived from B-cells, endothelial cells, and dendritic cells, express ICAM-1 (74, 108, 109), and endothelial cell-derived exosomes express CD44, CD166, PECAM, and B-CAM (74). Reticulocyte-derived exosomes have been shown to bind to fibronectin via integrin $\alpha 4 \beta 1$ (110). B-cell-derived exosomes contain $\beta 1$ and $\beta 2$ integrins, which were able to bind to collagen1 , fibronectin, and TNF- $\alpha$ activated fibroblasts (108). Exosomes derived from dendritic cells have also been reported to contain integrins (111). These studies show that EV may not only bind to and interact with cells, but also bind to various ECM components. It has been suggested that EV could adhere to the ECM to form a gradient or potential reservoir that could be released in case of inflammation or ECM degradation (108).

Besides molecules responsible for ECM interaction, EV have also been shown to express ECM-remodeling proteins, like matrix 
metalloproteinases (MMPs), which can degrade collagens, elastin, fibronectin, and laminin. These processes are important in ECM re-structuring, as well as cytokine release, angiogenesis, and cell migration $(112,113)$. For example, human fibrosarcoma and melanoma cell-derived exosomes contain both full length and proteolytically processed MMP14, shown to be enzymatically active since these exosomes activated pro-MMP2 resulting in the degradation of both collagen-1 and gelatin (114). Cardiomyocyte progenitor-derived exosomes expressed enzymatically active MMP2, as well as MMP-activator EMMPRIN (115). EMMPRIN has also been found on $\mathrm{CD}^{+}$T-cell microparticles, which have been shown to induce fibrolytic activation in hepatic stellate cells (70). Madin-Darby canine kidney cells (MDCK) that have undergone epithelial to mesenchymal transition (EMT) showed an increase in MMP1, -14, and -19 expression in their exosomes, as well as several integrins (116). Additionally, EV can also stimulate MMP production in target cells. Keratinocyte-like cells are able to stimulate MMP1 expression in dermal fibroblasts through transfer of several 14-3-3 isoforms by EV (117). Furthermore, monocyte and T-cell-derived microparticles are able to induce production of MMP-1, MMP-3, MMP-9, and MMP-13 in fibroblasts (68). Thus, EV can influence MMP abundance and activity on several levels.

Extracellular vesicles also have the ability to contribute to ECM strength. Members of the lysyl oxidase family crosslink collagens and elastin, increasing ECM load-bearing properties. Lysyl oxidase treatment of tissue-engineered cartilage constructs results in increased stiffness and enhanced cartilage integration, and lysyl oxidase-like 2 induces angiogenic sprouting through interacting with collagen- 4 in the basal membrane $(118,119)$. Lysyl oxidase was shown to be enriched in exosomes derived from hypoxic glyoma cells (98) and lysyl oxidase-like 2 in endothelial cells (74). Interestingly, exosomes from hypoxic endothelial cells also showed increased abundances of the ECM components fibronectin, collagen- 4 and -12 subunits, and perlecan, suggesting a hypoxia-mediated role in focal ECM modification by exosomes (74). EV are also able to affect local ECM production. Borges et al. found that upon hypoxic stimulation, epithelial cells stimulate fibroblasts through exosome-mediated TGF- $\beta 1$ signaling, resulting in increased collagen-1 production (91) and suggesting an exosome-mediated response resulting in local tissue repair. The effects of EV on both ECM production and remodeling could be of use in the steering of in situ ECM formation.

\section{IMMUNOMODULATION}

Modulating immune responses is vital in tissue engineering. The type and severity of the immune response against an implant depends on several factors including injury from surgery, the (bio)materials used, location of the graft, and the condition of the patient (120). An excessive or inappropriate immune response could result in damage, encapsulation or rejection of a tissueengineered construct. On the other hand, immune responses are potent triggers for regenerative processes, including cell recruitment, proliferation, and angiogenesis, which are key to the success of in situ tissue engineering (121).

When transplanting a tissue-engineered construct, the innate immune response consists of the acute and the chronic phase. The acute immune response is an immediate reaction against foreign structures, such as certain (bio)materials. An influx of neutrophils and macrophages induces the release of inflammatory cytokines, which results in local inflammation and the recruitment of additional immune cells. Cross-talk between macrophages and T-cells, as well as environmental cues, regulate a shift in macrophage sub-types in to either M1 (inflammatory), or the M2 (anti-inflammatory, regenerative) subtype (122). M1 macrophages promote recruitment of inflammatory immune cells, and release ECM-degrading proteins to allow quick migration through inflamed tissues. As the subtype of macrophages shifts to $\mathrm{M} 2$, pro-inflammatory cytokine release is inhibited, angiogenic stimulation is increased, and local fibroblasts are activated in order to produce and restore the ECM. Long-term inflammation results in a foreign body response (FBR) in which case a foreign tissue is encapsulated by a fibrous, barely vascularized connective scarlike tissue (123). An antibody-mediated immune response against allografts or tissues seeded with non-autologous cells could result in rejection of a graft. These findings underline the importance of tuning the immune response in tissue engineering: sufficient to induce vascularization, cell recruitment, and ECM production, while preventing fibrosis, tissue damage, and FBR.

The modulatory role of EV in innate immune responses could prove beneficial in tissue engineering. MSC-derived exosomes induced an M2-like phenotype in monocytes in vitro, resulting in polarization of activated CD4 T-cells to regulatory T-cells (124). Additionally, tumor-derived exosomes have been shown to induce a shift toward an activated M2 phenotype (125), as well as an M1 phenotype (126). Furthermore, EV can play a role in the suppression of allograft rejection. Autologous regulatory T-cellderived exosomes postponed allograft rejection in a rat kidney transplantation model (92). Immature dendritic cell-derived exosomes induced allograft tolerance in a cardiac allograft mouse model (127), as well as in a rat intestinal transplantation model (128) by increasing regulatory T-cell populations.

Mesenchymal stem cells themselves have been a tool of interest for their immunosuppressive capacities, inhibiting B- and T-cells, natural killer cells, macrophages, and dendritic cells (129131). Accordingly, MSC-derived exosomes promote secretion of anti-inflammatory cytokines, and contain an array of tolerogenic molecules (132), and administration of MSC-derived exosomes in a myocardial ischemia/reperfusion injury model showed a significant reduction of local and systemic inflammation after $24 \mathrm{~h}$ (133). In a renal ischemia-reperfusion model in rats, MSCderived microvesicles administered to the caudal vein inhibited inflammation as well as renal fibrosis (134). Indeed, a systematic literature study of MSC-derived EV revealed that modulation of EV responses, as well as repair of organ injury and suppression of tumor growth in preclinical studies, shows therapeutic potential (135).

The potential immunomodulatory role of EV may be relevant for regenerative medicine by steering vascularization, cell recruitment, and ECM formation, as well as the prevention of tissue damage, and FBR.

\section{EXTRACELLULAR VESICLES POTENTIAL}

All in all, EV show great potential for a role in regenerative medicine because of their role in cell recruitment, differentiation, and 
Table 1 | Functional relevance of EV in regenerative processes

\begin{tabular}{|c|c|c|}
\hline Process & Contribution & Reference \\
\hline \multirow[t]{3}{*}{$\begin{array}{l}\text { Cell senescence, viability } \\
\text { and proliferation }\end{array}$} & $\begin{array}{l}\text { Inhibition of cellular } \\
\text { senescence }\end{array}$ & 13 \\
\hline & Inhibition of apoptosis & $81-85$ \\
\hline & Increased cell proliferation & $\begin{array}{l}81,83,86 \\
89-91\end{array}$ \\
\hline \multirow[t]{4}{*}{ Angiogenesis } & $\begin{array}{l}\text { Transfer of pro-angiogenic } \\
\text { proteins }\end{array}$ & 96 \\
\hline & $\begin{array}{l}\text { Transfer of pro-angiogenic } \\
\text { miRNAs }\end{array}$ & 105 \\
\hline & Notch signaling & 101 \\
\hline & $\begin{array}{l}\text { Inhibition of endothelial } \\
\text { senescence }\end{array}$ & 13 \\
\hline \multirow[t]{4}{*}{ ECM interactions } & $\begin{array}{l}\text { Formation of signaling } \\
\text { reservoir in ECM }\end{array}$ & 108 \\
\hline & $\begin{array}{l}\text { ECM remodeling through } \\
\text { MMPs }\end{array}$ & $\begin{array}{l}68,70 \\
115-117\end{array}$ \\
\hline & $\begin{array}{l}\text { ECM crosslinking by lysyl } \\
\text { oxidases }\end{array}$ & 74,98 \\
\hline & Inducing ECM production & 91 \\
\hline \multirow[t]{4}{*}{ Immunomodulation } & $\begin{array}{l}\text { Steering M1-M2 } \\
\text { macrophage phenotype }\end{array}$ & $124-126$ \\
\hline & $\begin{array}{l}\text { Increasing regulatory T-cell } \\
\text { population }\end{array}$ & 128 \\
\hline & Decreasing graft rejection & $85,127,128$ \\
\hline & $\begin{array}{l}\text { Promoting anti-inflammatory } \\
\text { cytokine secretion }\end{array}$ & 132 \\
\hline
\end{tabular}

An overview of potential roles of $E V$ in regenerative medicine.

immunomodulation (Table 1). Many of these functions of EV may also be combined with other regenerative strategies as their effects on nutrient and oxygen supply, immune responses, and cell viability and senescence may benefit efficacy of approaches in regenerative medicine, such as cell therapies or in situ tissue engineering $(27,75,93)$. Given the role of $\mathrm{EV}$ in processes that greatly affect tissue regeneration, further studies in EV-mediated paracrine signaling and exploration of new methods to utilize EV or components thereof is warranted and may lead to the discovery of novel regenerative therapeutics, as well as methods to improve current techniques.

\section{APPLICATIONS OF EXTRACELLULAR VESICLES IN REGENERATIVE MEDICINE}

Even though, the existence of EV was discovered decades ago, interest in their role as paracrine factor was only relatively recently sparked. Much remains unknown about the pathways that determine the content of $\mathrm{EV}$, and many tissue-specific functions of $\mathrm{EV}$ remain to be uncovered. Future studies will provide new insights in $\mathrm{EV}$ function and biogenesis, and reveal the roles of proteins and miRNAs in EV function. EV are important components of the secretome involved in intercellular communication, of which content and function can change depending on the conditions of the vesicle producing cells $(74,91,102-104)$. Therefore, changes in EV content upon stimulation of producing cells with conditions relevant in development, tissue regeneration, and wound repair may reveal new pathways and insights in intercellular signaling that play key roles in these conditions. Altogether, these qualities make EV an interesting target for the potential discovery of new therapeutics in regenerative medicine.

\section{EXTRACELLULAR VESICLES AS THERAPEUTICS}

Extracellular vesicles from specific cell types and conditions have positive effects on regeneration in many tissues (136). It has also been observed that certain EV display multiple functions. For instance, MSC-derived EV are able to steer cell viability, proliferation, angiogenesis, and immune responses (81-83, 103, 104, 124, 132). Harnessing the paracrine effects of stem- and progenitor cells without having to administer living, replicating, potentially pluripotent cell populations is an advantage in regard to safety, regulation, and complexity.

However, there are challenges to overcome. The current golden standard in isolation of functional $\mathrm{EV}$ remains ultracentrifugation (58), which is a time-consuming and costly procedure that requires a large amount of cells. Although faster commercial reagents are available, which isolate higher yields of $\mathrm{EV}$, these products still require optimization in specificity as they have been reported to also precipitate non-EV contaminants such as lipoproteins (137). Despite decades of research, EV cargo trafficking pathways have not completely been elucidated, and therefore control over the content of EV, and unspecific additional effects, is limited. Research in both biogenesis of $\mathrm{EV}$, as well as techniques for engineering for artificial alternatives for $\mathrm{EV}$ is therefore warranted.

\section{EXTRACELLULAR VESICLES MODIFICATION}

The concept of developing synthetic alternatives for EV is motivated by the challenges that have been described above: the ability to form synthetic EVs would allow control over these elements, which would facilitate clinical translation. The approach could vary from modulation of biological EV synthesis to a purely synthetic production method. In the first approach, the EVs are still harvested from cells, but the producing cells have been engineered to enrich EVs with tags or therapeutic molecules. Incorporated tags could be used to assist in EV purification, or for targeting toward specific tissues, cells, or synthetic scaffolds. Also, the therapeutic payload can be enriched by overexpression of specific RNAs or proteins $(138,139)$.

More control over EV content can be achieved by a semisynthetic approach, which is based on techniques used in the therapeutic enveloped virus-field. Here, the viral envelope is solubilized in a high critical micelle concentration detergent. As a result the proteins and lipids that are part of the envelope are present in micelles that can be separated from the viral capsid. By removing the detergent, the envelope is reconstituted, and "virosomes" are formed (140). Translating this approach to EVs may improve the control over the composition of the bilayer, which additionally can be enriched with desired molecules, as well as during 
the reconstitution step, offering full control over the encapsulated (therapeutic) compounds in the aqueous core. At the same time, the naturally encapsulated molecules are removed.

\section{SYNTHETIC EXTRACELLULAR VESICLES}

The semi-synthetic approach still relies on the biological production of vesicles. The power of synthetic strategies lies in the scalability of the process. The minimal EV mimic is already on the market and is known as liposomes (141). Liposomes consist of a phospholipid bilayer around an aqueous core, and have been investigated as therapeutic delivery systems over the last 40 years. Therapeutic liposomes tend to be around $100 \mathrm{~nm}$ in size and have a lipid composition that allows them to circulate for prolonged periods in the blood stream. Generally, therapeutic liposomes are prepared in batches that vary between liters to hundreds of liters in size, with a colloidal stability of several years, even in solution. Still the translation of liposome technology to mimic EVs has some obstacles to overcome. For instance, the lipid and protein composition of EV, which may be important for their cellular interactions, is often complex, and the current production process of liposomes involves simple synthetic lipid mixtures without other components within the bilayer. However, liposomes have been successfully equipped with targeting ligands (such as antibodies) and a variety of therapeutic payloads including biologicals (142). These characteristics are several orders of magnitude away from the current state of the art in the EV field, but do illustrate the potential value of synthetic $\mathrm{EV}$.

\section{CONCLUSION}

Over the past decades, it has been shown that EV play a regulatory role, and have modulatory potential, in many biological processes. EV show great potential for therapeutics, biomarker research, and even alternatives to stem-cell-based therapies which rely on paracrine effects. These new approaches have great potential for the support of endogenous repair, including enhancements of existing regenerative medicine approaches. This potential merits further research in the potential of EV, as well the study of new techniques to produce and utilize engineered EV.

\section{ACKNOWLEDGMENTS}

This work was made possible by the multidisciplinary collaboration on Regenerative Medicine between the University Medical Center Utrecht and Eindhoven University of Technology (Marianne C. Verhaar and Carlijn V. C. Bouten), Olivier G. De Jong and Bas W. M. Van Balkom are supported by The Netherlands Institute for Regenerative Medicine (NIRM, grant No. FES0908), Raymond M. Schiffelers is supported by ERC Starting Grant MINDS (No. 260627) and Marianne C. Verhaar is supported by The Netherlands Organization for Scientific Research (Vidi grant 016.096.359).

\section{REFERENCES}

1. Harrison JH, Merrill JP, Murray JE. Renal homotransplantation in identical twins. Surg Forum (1956) 6:432-6.

2. Lexer E. The use of free osteoplasty together with trials on arthrodesis and joint transplantation. Archiv fur klin Chirurgie. 1908;86(4):939-954. Clin Orthop Relat Res (2008) 466(8):1771-6. doi:10.1007/s11999-008-0314-4

3. Zirm EK. Eine erfolgreiche totale Keratoplastik (A successful total keratoplasty). 1906. Refract Corneal Surg (1989) 5(4):258-61.
4. Drury JL, Mooney DJ. Hydrogels for tissue engineering: scaffold design variables and applications. Biomaterials (2003) 24(24):4337-51. doi:10.1016/ S0142-9612(03)00340-5

5. Mol A, Driessen NJ, Rutten MC, Hoerstrup SP, Bouten CV, Baaijens FP. Tissue engineering of human heart valve leaflets: a novel bioreactor for a strain-based conditioning approach. Ann Biomed Eng (2005) 33(12):1778-88. doi:10.1007/s10439-005-8025-4

6. Wagers AJ, Sherwood RI, Christensen JL, Weissman IL. Little evidence for developmental plasticity of adult hematopoietic stem cells. Science (2002) 297(5590):2256-9. doi:10.1126/science.1074807

7. Murry CE, Soonpaa MH, Reinecke H, Nakajima H, Nakajima HO, Rubart $\mathrm{M}$, et al. Haematopoietic stem cells do not transdifferentiate into cardiac myocytes in myocardial infarcts. Nature (2004) 428(6983):664-8. doi:10.1038/ nature 02446

8. Den Haan MC, Grauss RW, Smits AM, Winter EM, van Tuyn J, Pijnappels DA, et al. Cardiomyogenic differentiation-independent improvement of cardiac function by human cardiomyocyte progenitor cell injection in ischaemic mouse hearts. J Cell Mol Med (2012) 16(7):1508-21. doi:10.1111/j.1582-4934. 2011.01468.x

9. Van Koppen A, Joles JA, Bongartz LG, van den Brandt J, Reichardt HM, Goldschmeding R, et al. Healthy bone marrow cells reduce progression of kidney failure better than CKD bone marrow cells in rats with established chronic kidney disease. Cell Transplant (2012) 21(10):2299-312. doi:10.3727/ 096368912 X636795

10. Janowska-Wieczorek A, Wysoczynski M, Kijowski J, Marquez-Curtis L, Machalinski B, Ratajczak J, et al. Microvesicles derived from activated platelets induce metastasis and angiogenesis in lung cancer. Int J Cancer (2005) 113(5):752-60. doi:10.1002/ijc.20657

11. Mu W, Rana S, Zoller M. Host matrix modulation by tumor exosomes promotes motility and invasiveness. Neoplasia (2013) 15(8):875-87. doi:10.1593/ neo. 13786

12. Raposo G, Nijman HW, Stoorvogel W, Liejendekker R, Harding CV, Melief CJ, et al. B lymphocytes secrete antigen-presenting vesicles. J Exp Med (1996) 183(3):1161-72. doi:10.1084/jem.183.3.1161

13. Van Balkom BW, de Jong OG, Smits M, Brummelman J, den Ouden K, de Bree $\mathrm{PM}$, et al. Endothelial cells require miR-214 to secrete exosomes that suppress senescence and induce angiogenesis in human and mouse endothelial cells. Blood (2013) 121(19):3997-4006. doi:10.1182/blood-2013-02-478925

14. Thomas ED, Lochte HL Jr, Lu WC, Ferrebee JW. Intravenous infusion of bone marrow in patients receiving radiation and chemotherapy. N Engl J Med (1957) 257(11):491-6. doi:10.1056/NEJM195709122571102

15. Blundell J. Experiments on the transfusion of blood by the syringe. Med Chir Trans (1818) 9(Pt 1):56-92.

16. Slaper-Cortenbach IC. Current regulations for the production of multipotent mesenchymal stromal cells for clinical application. Transfus Med Hemother (2008) 35(4):295-8. doi:10.1159/000144043

17. Nishida K, Yamato M, Hayashida Y, Watanabe K, Yamamoto K, Adachi E, et al. Corneal reconstruction with tissue-engineered cell sheets composed of autologous oral mucosal epithelium. N Engl J Med (2004) 351(12):1187-96. doi:10.1056/NEJMoa040455

18. Bartlett W, Skinner JA, Gooding CR, Carrington RW, Flanagan AM, Briggs TW, et al. Autologous chondrocyte implantation versus matrix-induced autologous chondrocyte implantation for osteochondral defects of the knee: a prospective, randomised study. J Bone Joint Surg Br (2005) 87(5):640-5. doi:10.1302/0301-620X.87B5.15905

19. Schwarz TM, Leicht SF, Radic T, Rodriguez-Araboalaza I, Hermann PC, Berger $\mathrm{F}$, et al. Vascular incorporation of endothelial colony-forming cells is essentia for functional recovery of murine ischemic tissue following cell therapy. Arterioscler Thromb Vasc Biol (2012) 32(2):e13-21. doi:10.1161/ATVBAHA.111. 239822

20. Beltrami AP, Cesselli D, Beltrami CA. Stem cell senescence and regenerative paradigms. Clin Pharmacol Ther (2012) 91(1):21-9. doi:10.1038/clpt.2011.262

21. Siddappa R, Licht R, van Blitterswijk C, de Boer J. Donor variation and loss of multipotency during in vitro expansion of human mesenchymal stem cells for bone tissue engineering. J Orthop Res (2007) 25(8):1029-41. doi:10.1002/jor.20402

22. Engler AJ, Sen S, Sweeney HL, Discher DE. Matrix elasticity directs stem cell lineage specification. Cell (2006) 126(4):677-89. doi:10.1016/j.cell.2006.06.044 
23. Jie KE, Zaikova MA, Bergevoet MW, Westerweel PE, Rastmanesh M, Blankestijn PJ, et al. Progenitor cells and vascular function are impaired in patients with chronic kidney disease. Nephrol Dial Transplant (2010) 25(6):1875-82. doi:10.1093/ndt/gfp749

24. Scruggs BA, Semon JA, Zhang X, Zhang S, Bowles AC, Pandey AC, et al. Age of the donor reduces the ability of human adipose-derived stem cells to alleviate symptoms in the experimental autoimmune encephalomyelitis mouse model. Stem Cells Transl Med (2013) 2(10):797-807. doi:10.5966/sctm.2013-0026

25. Williamson KA, Hamilton A, Reynolds JA, Sipos P, Crocker I, Stringer SE, et al. Age-related impairment of endothelial progenitor cell migration correlates with structural alterations of heparan sulfate proteoglycans. Aging Cell (2013) 12(1):139-47. doi:10.1111/acel.12031

26. Hugle T, Daikeler T. Stem cell transplantation for autoimmune diseases. Haematologica (2010) 95(2):185-8. doi:10.3324/haematol.2009.017038

27. Muylaert DE, Fledderus JO, Bouten CV, Dankers PY, Verhaar MC. Combining tissue repair and tissue engineering; bioactivating implantable cell-free vascular scaffolds. Heart (2014) 100(23):1825-30. doi:10.1136/heartjnl-2014-306092

28. Vanden Berg-Foels WS. In situ tissue regeneration: chemoattractants for endogenous stem cell recruitment. Tissue Eng Part B Rev (2014) 20(1):28-39. doi:10.1089/ten.teb. 2013.0100

29. Badylak SF. Xenogeneic extracellular matrix as a scaffold for tissue reconstruction. Transpl Immunol (2004) 12(3-4):367-77. doi:10.1016/j.trim.2003.12.016

30. Knight RL, Wilcox HE, Korossis SA, Fisher J, Ingham E. The use of acellular matrices for the tissue engineering of cardiac valves. Proc Inst Mech Eng $H$ (2008) 222(1):129-43. doi:10.1243/09544119JEIM230

31. Borschel GH, Huang YC, Calve S, Arruda EM, Lynch JB, Dow DE, et al. Tissue engineering of recellularized small-diameter vascular grafts. Tissue Eng (2005) 11(5-6):778-86. doi:10.1089/ten.2005.11.778

32. Baiguera S, Jungebluth P, Burns A, Mavilia C, Haag J, De Coppi P, et al. Tissue engineered human tracheas for in vivo implantation. Biomaterials (2010) 31(34):8931-8. doi:10.1016/j.biomaterials.2010.08.005

33. Zheng MH, Chen J, Kirilak Y, Willers C, Xu J, Wood D. Porcine small intestine submucosa (SIS) is not an acellular collagenous matrix and contains porcine DNA: possible implications in human implantation. J Biomed Mater Res B Appl Biomater (2005) 73(1):61-7. doi:10.1002/jbm.b.30170

34. Ratner BD, Bryant SJ. Biomaterials: where we have been and where we are going. Annu Rev Biomed Eng (2004) 6:41-75. doi:10.1146/annurev.bioeng.6. 040803.140027

35. Mendelson K, Schoen FJ. Heart valve tissue engineering: concepts, approaches, progress, and challenges. Ann Biomed Eng (2006) 34(12):1799-819. doi:10. 1007/s10439-006-9163-z

36. Mikos AG, Lyman MD, Freed LE, Langer R. Wetting of poly(L-lactic acid) and poly(DL-lactic-co-glycolic acid) foams for tissue culture. Biomaterials (1994) 15(1):55-8. doi:10.1016/0142-9612(94)90197-X

37. Whang K, Thomas CH, Healy KE, Nuber G. A novel method to fabricate bioabsorbable scaffolds. Polymer (1995) 36(4):837-42. doi:10.1016/0032-3861(95) 93115-3

38. Mooney DJ, Baldwin DF, Suh NP, Vacanti JP, Langer R. Novel approach to fabricate porous sponges of poly(D,L-lactic-co-glycolic acid) without the use of organic solvents. Biomaterials (1996) 17(14):1417-22. doi:10.1016/01429612(96)87284-X

39. Mooney DJ, Mazzoni CL, Breuer C, McNamara K, Hern D, Vacanti JP, et al. Stabilized polyglycolic acid fibre-based tubes for tissue engineering. Biomaterials (1996) 17(2):115-24. doi:10.1016/0142-9612(96)85756-5

40. Stankus JJ, Guan J, Wagner WR. Fabrication of biodegradable elastomeric scaffolds with sub-micron morphologies. J Biomed Mater Res A (2004) 70(4):603-14. doi:10.1002/jbm.a.30122

41. Li M, Mondrinos MJ, Chen X, Gandhi MR, Ko FK, Lelkes PI. Co-electrospun poly(lactide-co-glycolide), gelatin, and elastin blends for tissue engineering scaffolds. J Biomed Mater Res A (2006) 79(4):963-73. doi:10.1002/jbm.a.30833

42. Choi WS, Bae JW, Lim HR, Joung YK, Park JC, Kwon IK, et al. RGD peptide-immobilized electrospun matrix of polyurethane for enhanced endothelial cell affinity. Biomed Mater (2008) 3(4):044104. doi:10.1088/17486041/3/4/044104

43. Yu J, Lee AR, Lin WH, Lin CW, Wu YK, Tsai WB. Electrospun PLGA fibers incorporated with functionalized biomolecules for cardiac tissue engineering. Tissue Eng Part A (2014) 20(13-14):1896-907. doi:10.1089/ten.tea.2013.0008

44. Kolambkar YM, Bajin M, Wojtowicz A, Hutmacher DW, Garcia AJ, Guldberg RE. Nanofiber orientation and surface functionalization modulate human mesenchymal stem cell behavior in vitro. Tissue Eng Part A (2014) 20(12):398-409. doi:10.1089/ten.tea.2012.0426

45. Han F, Jia X, Dai D, Yang X, Zhao J, Zhao Y, et al. Performance of a multilayered small-diameter vascular scaffold dual-loaded with VEGF and PDGF Biomaterials (2013) 34(30):7302-13. doi:10.1016/j.biomaterials.2013.06.006

46. Thevenot PT, Nair AM, Shen J, Lotfi P, Ko CY, Tang L. The effect of incorporation of SDF-1alpha into PLGA scaffolds on stem cell recruitment and the inflammatory response. Biomaterials (2010) 31(14):3997-4008. doi:10.1016/j. biomaterials.2010.01.144

47. De Visscher G, Mesure L, Meuris B, Ivanova A, Flameng W. Improved endothelialization and reduced thrombosis by coating a synthetic vascular graft with fibronectin and stem cell homing factor SDF-lalpha. Acta Biomater (2012) 8(3):1330-8. doi:10.1016/j.actbio.2011.09.016

48. Tsai TN, Kirton JP, Campagnolo P, Zhang L, Xiao Q, Zhang Z, et al. Contribution of stem cells to neointimal formation of decellularized vessel grafts in a novel mouse model. Am J Pathol (2012) 181(1):362-73. doi:10.1016/j.ajpath. 2012.03.021

49. Lai RC, Arslan F, Lee MM, Sze NS, Choo A, Chen TS, et al. Exosome secreted by MSC reduces myocardial ischemia/reperfusion injury. Stem Cell Res (2010) 4(3):214-22. doi:10.1016/j.scr.2009.12.003

50. Stoorvogel W, Kleijmeer MJ, Geuze HJ, Raposo G. The biogenesis and functions of exosomes. Traffic (2002) 3(5):321-30. doi:10.1034/j.1600-0854.2002. 30502.x

51. Thery C, Zitvogel L, Amigorena S. Exosomes: composition, biogenesis and function. Nat Rev Immunol (2002) 2(8):569-79. doi:10.1038/nri855

52. Valadi H, Ekstrom K, Bossios A, Sjostrand M, Lee JJ, Lotvall JO. Exosomemediated transfer of mRNAs and microRNAs is a novel mechanism of genetic exchange between cells. Nat Cell Biol (2007) 9(6):654-9. doi:10.1038/ncb1596

53. Bobrie A, Colombo M, Raposo G, Thery C. Exosome secretion: molecular mechanisms and roles in immune responses. Traffic (2011) 12(12):1659-68. doi:10.1111/j.1600-0854.2011.01225.x

54. Gutzeit C, Nagy N, Gentile M, Lyberg K, Gumz J, Vallhov H, et al. Exosomes derived from Burkitt's lymphoma cell lines induce proliferation, differentiation, and class-switch recombination in B cells. J Immunol (2014) 192(12):5852-62. doi:10.4049/jimmunol.1302068

55. Pan BT, Johnstone RM. Fate of the transferrin receptor during maturation of sheep reticulocytes in vitro: selective externalization of the receptor. Cell (1983) 33(3):967-78. doi:10.1016/0092-8674(83)90040-5

56. Xu D, Tahara $\mathrm{H}$. The role of exosomes and microRNAs in senescence and aging. Adv Drug Deliv Rev (2013) 65(3):368-75. doi:10.1016/j.addr.2012.07.010

57. El Andaloussi S, Lakhal S, Mager I, Wood MJ. Exosomes for targeted siRNA delivery across biological barriers. Adv Drug Deliv Rev (2013) 65(3):391-7. doi:10.1016/j.addr.2012.08.008

58. Gould SJ, Raposo G. As we wait: coping with an imperfect nomenclature for extracellular vesicles. J Extracell Vesicles (2013) 2:20389. doi:10.3402/jev.v2i0. 20389

59. van Balkom BW, Pisitkun T, Verhaar MC, Knepper MA. Exosomes and the kidney: prospects for diagnosis and therapy of renal diseases. Kidney Int (2011) 80(11):1138-45. doi:10.1038/ki.2011.292

60. Escola JM, Kleijmeer MJ, Stoorvogel W, Griffith JM, Yoshie O, Geuze HJ. Selective enrichment of tetraspan proteins on the internal vesicles of multivesicular endosomes and on exosomes secreted by human B-lymphocytes. J Biol Chem (1998) 273(32):20121-7. doi:10.1074/jbc.273.32.20121

61. Vader P, Breakefield XO, Wood MJ. Extracellular vesicles: emerging targets for cancer therapy. Trends Mol Med (2014) 20(7):385-93. doi:10.1016/j.molmed. 2014.03.002

62. Cocucci E, Racchetti G, Meldolesi J. Shedding microvesicles: artefacts no more. Trends Cell Biol (2009) 19(2):43-51. doi:10.1016/j.tcb.2008.11.003

63. Baj-Krzyworzeka M, Szatanek R, Weglarczyk K, Baran J, Urbanowicz B, Branski $\mathrm{P}$, et al. Tumour-derived microvesicles carry several surface determinants and mRNA of tumour cells and transfer some of these determinants to monocytes. Cancer Immunol Immunother (2006) 55(7):808-18. doi:10.1007/s00262-005-0075-9

64. Ratajczak J, Wysoczynski M, Hayek F, Janowska-Wieczorek A, Ratajczak MZ. Membrane-derived microvesicles: important and underappreciated mediators of cell-to-cell communication. Leukemia (2006) 20(9):1487-95. doi:10.1038/ sj.leu. 2404296

65. Huber J, Vales A, Mitulovic G, Blumer M, Schmid R, Witztum JL, et al. Oxidized membrane vesicles and blebs from apoptotic cells contain 
biologically active oxidized phospholipids that induce monocyte-endothelial interactions. Arterioscler Thromb Vasc Biol (2002) 22(1):101-7. doi:10.1161/ hq0102.101525

66. Loyer X, Vion AC, Tedgui A, Boulanger CM. Microvesicles as cell-cell messengers in cardiovascular diseases. Circ Res (2014) 114(2):345-53. doi:10.1161/ CIRCRESAHA.113.300858

67. Zernecke A, Bidzhekov K, Noels H, Shagdarsuren E, Gan L, Denecke B, et al. Delivery of microRNA-126 by apoptotic bodies induces CXCL12dependent vascular protection. Sci Signal (2009) 2(100):ra81. doi:10.1126/ scisignal.2000610

68. Distler JH, Jungel A, Huber LC, Seemayer CA, Reich CF III, Gay RE, et al. The induction of matrix metalloproteinase and cytokine expression in synovial fibroblasts stimulated with immune cell microparticles. Proc Natl Acad Sci U S A (2005) 102(8):2892-7. doi:10.1073/pnas.0409781102

69. Julich H, Willms A, Lukacs-Kornek V, Kornek M. Extracellular vesicle profiling and their use as potential disease specific biomarker. Front Immunol (2014) 5:413. doi:10.3389/fimmu.2014.00413

70. Kornek M, Popov Y, Libermann TA, Afdhal NH, Schuppan D. Human T cell microparticles circulate in blood of hepatitis patients and induce fibrolytic activation of hepatic stellate cells. Hepatology (2011) 53(1):230-42. doi:10.1002/ hep. 23999

71. Harding C, Heuser J, Stahl P. Receptor-mediated endocytosis of transferrin and recycling of the transferrin receptor in rat reticulocytes. J Cell Biol (1983) 97(2):329-39. doi:10.1083/jcb.97.2.329

72. Johnstone RM, Mathew A, Mason AB, Teng K. Exosome formation during maturation of mammalian and avian reticulocytes: evidence that exosome release is a major route for externalization of obsolete membrane proteins. J Cell Physiol (1991) 147(1):27-36. doi:10.1002/jcp.1041470105

73. Pegtel DM, Cosmopoulos K, Thorley-Lawson DA, van Eijndhoven MA, Hopmans ES, Lindenberg JL, et al. Functional delivery of viral miRNAs via exosomes. Proc Natl Acad Sci U S A (2010) 107(14):6328-33. doi:10.1073/pnas. 0914843107

74. De Jong OG, Verhaar MC, Chen Y, Vader P, Gremmels H, Posthuma G, et al. Cellular stress conditions are reflected in the protein and RNA content of endothelial cell-derived exosomes. J Extracell Vesicles (2012) 1:18396. doi:10.3402/jev.vli0.18396

75. Huu AL, Paul A, Prakash S, Shum-Tim D. Route of delivery, cell retention, and efficiency of polymeric microcapsules in cellular cardiomyoplasty. Methods $\mathrm{Mol}$ Biol (2013) 1036:121-35. doi:10.1007/978-1-62703-511-8_11

76. Gruber HE, Somayaji S, Riley F, Hoelscher GL, Norton HJ, Ingram J, et al. Human adipose-derived mesenchymal stem cells: serial passaging, doubling time and cell senescence. Biotech Histochem (2012) 87(4):303-11. doi:10.3109/ 10520295.2011.649785

77. Stolzing A, Jones E, McGonagle D, Scutt A. Age-related changes in human bone marrow-derived mesenchymal stem cells: consequences for cell therapies. Mech Ageing Dev (2008) 129(3):163-73. doi:10.1016/j.mad.2007.12.002

78. Adijiang A, Higuchi Y, Nishijima F, Shimizu H, Niwa T. Indoxyl sulfate, a uremic toxin, promotes cell senescence in aorta of hypertensive rats. Biochem Biophys Res Commun (2010) 399(4):637-41. doi:10.1016/j.bbrc.2010.07.130

79. Bonab MM, Alimoghaddam K, Talebian F, Ghaffari SH, Ghavamzadeh A, Nikbin B. Aging of mesenchymal stem cell in vitro. BMC Cell Biol (2006) 7:14. doi:10.1186/1471-2121-7-14

80. Vacanti V, Kong E, Suzuki G, Sato K, Canty JM, Lee T. Phenotypic changes of adult porcine mesenchymal stem cells induced by prolonged passaging in culture. J Cell Physiol (2005) 205(2):194-201. doi:10.1002/jcp.20376

81. Zhou Y, Xu H, Xu W, Wang B, Wu H, Tao Y, et al. Exosomes released by human umbilical cord mesenchymal stem cells protect against cisplatin-induced renal oxidative stress and apoptosis in vivo and in vitro. Stem Cell Res Ther (2013) 4(2):34. doi: $10.1186 /$ scrt194

82. Barile L, Lionetti V, Cervio E, Matteucci M, Gherghiceanu M, Popescu LM, et al. Extracellular vesicles from human cardiac progenitor cells inhibit cardiomyocyte apoptosis and improve cardiac function after myocardial infarction. Cardiovasc Res (2014) 103(4):530-41. doi:10.1093/cvr/cvul67

83. Reis LA, Borges FT, Simoes MJ, Borges AA, Sinigaglia-Coimbra R, Schor N. Bone marrow-derived mesenchymal stem cells repaired but did not prevent gentamicin-induced acute kidney injury through paracrine effects in rats. PLoS One (2012) 7(9):e44092. doi:10.1371/journal.pone.0044092

84. Bruno S, Grange C, Collino F, Deregibus MC, Cantaluppi V, Biancone L, et al. Microvesicles derived from mesenchymal stem cells enhance survival in a lethal model of acute kidney injury. PLoS One (2012) 7(3):e33115. doi:10.1371/journal.pone.0033115

85. Yu B, Gong M, Wang Y, Millard RW, Pasha Z, Yang Y, et al. Cardiomyocyte protection by GATA-4 gene engineered mesenchymal stem cells is partially mediated by translocation of miR-221 in microvesicles. PLoS One (2013) 8(8):e73304. doi:10.1371/journal.pone.0073304

86. Inder KL, Ruelcke JE, Petelin L, Moon H, Choi E, Rae J, et al. Cavin1/PTRF alters prostate cancer cell-derived extracellular vesicle content and internalization to attenuate extracellular vesicle-mediated osteoclastogenesis and osteoblast proliferation. J Extracell Vesicles (2014) 3:23784. doi:10.3402/ jev.v3.23784

87. Xu Y, Luo F, Liu Y, Shi L, Lu X, Xu W, et al. Exosomal miR-21 derived from arsenite-transformed human bronchial epithelial cells promotes cell proliferation associated with arsenite carcinogenesis. Arch Toxicol (2014). doi:10.1007/s00204-014-1291-x

88. Yang L, Wu XH, Wang D, Luo CL, Chen LX. Bladder cancer cell-derived exosomes inhibit tumor cell apoptosis and induce cell proliferation in vitro. $\mathrm{Mol}$ Med Rep (2013) 8(4):1272-8. doi:10.3892/mmr.2013.1634

89. Tomasoni S, Longaretti L, Rota C, Morigi M, Conti S, Gotti E, et al. Transfer of growth factor receptor mRNA via exosomes unravels the regenerative effect of mesenchymal stem cells. Stem Cells Dev (2013) 22(5):772-80. doi:10.1089/scd.2012.0266

90. Zhang B, Wang M, Gong A, Zhang X, Wu X, Zhu Y, et al. HucMSC-exosome mediated-Wnt4 signaling is required for cutaneous wound healing. Stem Cells (2014). doi:10.1002/stem.1771

91. Borges FT, Melo SA, Ozdemir BC, Kato N, Revuelta I, Miller CA, et al. TGFbetal-containing exosomes from injured epithelial cells activate fibroblasts to initiate tissue regenerative responses and fibrosis. J Am Soc Nephrol (2013) 24(3):385-92. doi:10.1681/ASN.2012101031

92. Yu X, Huang C, Song B, Xiao Y, Fang M, Feng J, et al. CD4+CD25+ regulatory $\mathrm{T}$ cells-derived exosomes prolonged kidney allograft survival in a rat model. Cell Immunol (2013) 285(1-2):62-8. doi:10.1016/j.cellimm.2013.06.010

93. Jain RK, Au P, Tam J, Duda DG, Fukumura D. Engineering vascularized tissue. Nat Biotechnol (2005) 23(7):821-3. doi:10.1038/nbt0705-821

94. Du C, Narayanan K, Leong MF, Wan AC. Induced pluripotent stem cellderived hepatocytes and endothelial cells in multi-component hydrogel fibers for liver tissue engineering. Biomaterials (2014) 35(23):6006-14. doi:10.1016/ j.biomaterials.2014.04.011

95. Glynn JJ, Hinds MT. Endothelial outgrowth cells: function and performance in vascular grafts. Tissue Eng Part B Rev (2013) 20(4):294-303. doi:10.1089/ten. teb. 2013.0285

96. Ekstrom EJ, Bergenfelz C, von Bulow V, Serifler F, Carlemalm E, Jonsson G, et al WNT5A induces release of exosomes containing pro-angiogenic and immunosuppressive factors from malignant melanoma cells. Mol Cancer (2014) 13:88. doi:10.1186/1476-4598-13-88

97. Hong BS, Cho JH, Kim H, Choi EJ, Rho S, Kim J, et al. Colorectal cancer cell-derived microvesicles are enriched in cell cycle-related mRNAs that promote proliferation of endothelial cells. BMC Genomics (2009) 10:556. doi:10.1186/1471-2164-10-556

98. Kucharzewska P, Christianson HC, Welch JE, Svensson KJ, Fredlund E, Ringner M, et al. Exosomes reflect the hypoxic status of glioma cells and mediate hypoxia-dependent activation of vascular cells during tumor development. Proc Natl Acad Sci U S A (2013) 110(18):7312-7. doi:10.1073/pnas. 1220998110

99. Skog J, Wurdinger T, van Rijn S, Meijer DH, Gainche L, Sena-Esteves M, et al. Glioblastoma microvesicles transport RNA and proteins that promote tumour growth and provide diagnostic biomarkers. Nat Cell Biol (2008) 10(12):1470-6. doi: $10.1038 /$ ncb 1800

100. Tadokoro H, Umezu T, Ohyashiki K, Hirano T, Ohyashiki JH. Exosomes derived from hypoxic leukemia cells enhance tube formation in endothelial cells. J Biol Chem (2013) 288(48):34343-51. doi:10.1074/jbc.M113.480822

101. Sheldon H, Heikamp E, Turley H, Dragovic R, Thomas P, Oon CE, et al. New mechanism for Notch signaling to endothelium at a distance by Delta-like 4 incorporation into exosomes. Blood (2010) 116(13):2385-94. doi:10.1182/ blood-2009-08-239228

102. Lopatina T, Bruno S, Tetta C, Kalinina N, Porta M, Camussi G. Platelet-derived growth factor regulates the secretion of extracellular vesicles by adipose mesenchymal stem cells and enhances their angiogenic potential. Cell Commun Signal (2014) 12:26. doi:10.1186/1478-811X-12-26 
103. Bian S, Zhang L, Duan L, Wang X, Min Y, Yu H. Extracellular vesicles derived from human bone marrow mesenchymal stem cells promote angiogenesis in a rat myocardial infarction model. J Mol Med (Berl) (2014) 92(4):387-97. doi:10.1007/s00109-013-1110-5

104. Zhang HC, Liu XB, Huang S, Bi XY, Wang HX, Xie LX, et al. Microvesicles derived from human umbilical cord mesenchymal stem cells stimulated by hypoxia promote angiogenesis both in vitro and in vivo. Stem Cells Dev (2012) 21(18):3289-97. doi:10.1089/scd.2012.0095

105. Cantaluppi V, Biancone L, Figliolini F, Beltramo S, Medica D, Deregibus MC, et al. Microvesicles derived from endothelial progenitor cells enhance neoangiogenesis of human pancreatic islets. Cell Transplant (2012) 21(6):1305-20. doi:10.3727/096368911X627534

106. Ranghino A, Cantaluppi V, Grange C, Vitillo L, Fop F, Biancone L, et al. Endothelial progenitor cell-derived microvesicles improve neovascularization in a murine model of hindlimb ischemia. Int J Immunopathol Pharmacol (2012) 25(1):75-85.

107. Sahoo S, Klychko E, Thorne T, Misener S, Schultz KM, Millay M, et al. Exosomes from human CD34(+) stem cells mediate their proangiogenic paracrine activity. Circ Res (2011) 109(7):724-8. doi:10.1161/CIRCRESAHA.111.253286

108. Clayton A, Turkes A, Dewitt S, Steadman R, Mason MD, Hallett MB. Adhesion and signaling by B cell-derived exosomes: the role of integrins. FASEB J (2004) 18(9):977-9. doi:10.1096/fj.03-1094fje

109. Segura E, Nicco C, Lombard B, Veron P, Raposo G, Batteux F, et al. ICAM-1 on exosomes from mature dendritic cells is critical for efficient naive T-cell priming. Blood (2005) 106(1):216-23. doi:10.1182/blood-2005-01-0220

110. Rieu S, Geminard C, Rabesandratana H, Sainte-Marie J, Vidal M. Exosomes released during reticulocyte maturation bind to fibronectin via integrin alpha4beta1. Eur J Biochem (2000) 267(2):583-90. doi:10.1046/j.1432-1327. 2000.01036.x

111. Thery C, Regnault A, Garin J, Wolfers J, Zitvogel L, Ricciardi-Castagnoli P, et al. Molecular characterization of dendritic cell-derived exosomes. Selective accumulation of the heat shock protein hsc73. J Cell Biol (1999) 147(3):599-610. doi:10.1083/jcb.147.3.599

112. Chen Q, Jin M, Yang F, Zhu J, Xiao Q, Zhang L. Matrix metalloproteinases: inflammatory regulators of cell behaviors in vascular formation and remodeling. Mediators Inflamm (2013) 2013:928315. doi:10.1155/2013/928315

113. Nissinen L, Kahari VM. Matrix metalloproteinases in inflammation. Biochim Biophys Acta (2014) 1840(8):2571-80. doi:10.1016/j.bbagen.2014.03.007

114. Hakulinen J, Sankkila L, Sugiyama N, Lehti K, Keski-Oja J. Secretion of active membrane type 1 matrix metalloproteinase (MMP-14) into extracellular space in microvesicular exosomes. J Cell Biochem (2008) 105(5):1211-8. doi:10.1002/jcb.21923

115. Vrijsen KR, Sluijter JP, Schuchardt MW, van Balkom BW, Noort WA, Chamuleau SA, et al. Cardiomyocyte progenitor cell-derived exosomes stimulate migration of endothelial cells. J Cell Mol Med (2010) 14(5):1064-70. doi:10.1111/j.1582-4934.2010.01081.x

116. Tauro BJ, Mathias RA, Greening DW, Gopal SK, Ji H, Kapp EA, et al. Oncogenic H-ras reprograms Madin-Darby canine kidney (MDCK) cell-derived exosomal proteins following epithelial-mesenchymal transition. Mol Cell Proteomics (2013) 12(8):2148-59. doi:10.1074/mcp.M112.027086

117. Medina A, Ghahary A. Transdifferentiated circulating monocytes release exosomes containing 14-3-3 proteins with matrix metalloproteinase-1 stimulating effect for dermal fibroblasts. Wound Repair Regen (2010) 18(2):245-53. doi:10.1111/j.1524-475X.2010.00580.x

118. Athens AA, Makris EA, Hu JC. Induced collagen cross-links enhance cartilage integration. PLoS One (2013) 8(4):e60719. doi:10.1371/journal.pone.0060719

119. Bignon M, Pichol-Thievend C, Hardouin J, Malbouyres M, Brechot N, Nasciutti $\mathrm{L}$, et al. Lysyl oxidase-like protein-2 regulates sprouting angiogenesis and type IV collagen assembly in the endothelial basement membrane. Blood (2011) 118(14):3979-89. doi:10.1182/blood-2010-10-313296

120. Hanson S, D'Souza RN, Hematti P. Biomaterial-mesenchymal stem cell constructs for immunomodulation in composite tissue engineering. Tissue Eng Part A (2014) 20(15-16):2162-8. doi:10.1089/ten.tea.2013.0359

121. Artlett CM. Inflammasomes in wound healing and fibrosis. J Pathol (2012) 229(2):157-67. doi:10.1002/path.4116

122. Galli SJ, Borregaard N, Wynn TA. Phenotypic and functional plasticity of cells of innate immunity: macrophages, mast cells and neutrophils. Nat Immunol (2011) 12(11):1035-44. doi:10.1038/ni.2109
123. Brown BN, Ratner BD, Goodman SB, Amar S, Badylak SF. Macrophage polarization: an opportunity for improved outcomes in biomaterials and regenerative medicine. Biomaterials (2012) 33(15):3792-802. doi:10.1016/j. biomaterials.2012.02.034

124. Zhang B, Yin Y, Lai RC, Tan SS, Choo AB, Lim SK. Mesenchymal stem cells secrete immunologically active exosomes. Stem Cells Dev (2014) 23(11):1233-44. doi:10.1089/scd.2013.0479

125. Soki FN, Koh AJ, Jones JD, Kim YW, Dai J, Keller ET, et al. Polarization of prostate cancer-associated macrophages is induced by milk fat globule-EGF factor 8 (MFG-E8)-mediated efferocytosis. J Biol Chem (2008) 289(35):24560-72. doi:10.1074/jbc.M114.571620

126. Jang JY, Lee JK, Jeon YK, Kim CW. Exosome derived from epigallocatechin gallate treated breast cancer cells suppresses tumor growth by inhibiting tumorassociated macrophage infiltration and M2 polarization. BMC Cancer (2013) 13:421. doi:10.1186/1471-2407-13-421

127. Li X, Li JJ, Yang JY, Wang DS, Zhao W, Song WJ, et al. Tolerance induction by exosomes from immature dendritic cells and rapamycin in a mouse cardiac allograft model. PLoS One (2013) 7(8):e44045. doi:10.1371/journal.pone. 0044045

128. Yang X, Meng S, Jiang H, Zhu C, Wu W. Exosomes derived from immature bone marrow dendritic cells induce tolerogenicity of intestinal transplantation in rats. J Surg Res (2011) 171(2):826-32. doi:10.1016/j.jss.2010.05.021

129. Corcione A, Benvenuto F, Ferretti E, Giunti D, Cappiello V, Cazzanti F, et al. Human mesenchymal stem cells modulate B-cell functions. Blood (2006) 107(1):367-72. doi:10.1182/blood-2005-07-2657

130. Shi M, Liu ZW, Wang FS. Immunomodulatory properties and therapeutic application of mesenchymal stem cells. Clin Exp Immunol (2011) 164(1):1-8. doi:10.1111/j.1365-2249.2011.04327.x

131. Xue Q, Luan XY, Gu YZ, Wu HY, Zhang GB, Yu GH, et al. The negative cosignaling molecule b7-h4 is expressed by human bone marrow-derived mesenchymal stem cells and mediates its T-cell modulatory activity. Stem Cells Dev (2010) 19(1):27-38. doi:10.1089/scd.2009.0076

132. Mokarizadeh A, Delirezh N, Morshedi A, Mosayebi G, Farshid AA, Mardani K. Microvesicles derived from mesenchymal stem cells: potent organelles for induction of tolerogenic signaling. Immunol Lett (2012) 147(1-2):47-54. doi:10.1016/j.imlet.2012.06.001

133. Arslan F, Lai RC, Smeets MB, Akeroyd L, Choo A, Aguor EN, et al. Mesenchymal stem cell-derived exosomes increase ATP levels, decrease oxidative stress and activate PI3K/Akt pathway to enhance myocardial viability and prevent adverse remodeling after myocardial ischemia/reperfusion injury. Stem Cell Res (2013) 10(3):301-12. doi:10.1016/j.scr.2013.01.002

134. Zou X, Zhang G, Cheng Z, Yin D, Du T, Ju G, et al. Microvesicles derived from human Wharton's Jelly mesenchymal stromal cells ameliorate renal ischemiareperfusion injury in rats by suppressing CX3CL1. Stem Cell Res Ther (2014) 5(2):40. doi: $10.1186 /$ scrt428

135. Akyurekli C, Le Y, Richardson RB, Fergusson D, Tay J, Allan DS. A systematic review of preclinical studies on the therapeutic potential of mesenchymal stromal cell-derived microvesicles. Stem Cell Rev Rep (2014). doi:10.1007/s12015014-9545-9

136. Lamichhane TN, Sokic S, Schardt JS, Raiker RS, Lin JW, Jay SM. Emerging roles for extracellular vesicles in tissue engineering and regenerative medicine. Tissue Eng Part B Rev (2014). doi:10.1089/ten.teb.2014.0300

137. Witwer KW, Buzas EI, Bemis LT, Bora A, Lasser C, Lotvall J, et al. Standardization of sample collection, isolation and analysis methods in extracellular vesicle research. J Extracell Vesicles (2013) 2:20360. doi:10.3402/jev.v2i0.20360

138. Li W, Mu D, Tian F, Hu Y, Jiang T, Han Y, et al. Exosomes derived from Rab27aoverexpressing tumor cells elicit efficient induction of antitumor immunity. Mol Med Rep (2013) 8(6):1876-82. doi:10.3892/mmr.2013.1738

139. Squadrito ML, Baer C, Burdet F, Maderna C, Gilfillan GD, Lyle R, et al. Endogenous RNAs modulate microRNA sorting to exosomes and transfer to acceptor cells. Cell Rep (2014) 8(5):1432-46. doi:10.1016/j.celrep.2014.07.035

140. Daemen T, de Mare A, Bungener L, de Jonge J, Huckriede A, Wilschut J. Virosomes for antigen and DNA delivery. Adv Drug Deliv Rev (2005) 57(3):451-63 doi:10.1016/j.addr.2004.09.005

141. van der Meel R, Fens MH, Vader P, van Solinge WW, Eniola-Adefeso O, Schiffelers RM. Extracellular vesicles as drug delivery systems: lessons from the liposome field. J Control Release (2014) 195:72-85. doi:10.1016/j. jconrel.2014.07.049 
142. van der Meel R, Vehmeijer LJ, Kok RJ, Storm G, van Gaal EV. Ligand-targeted particulate nanomedicines undergoing clinical evaluation: current status. $A d v$ Drug Deliv Rev (2013) 65(10):1284-98. doi:10.1016/j.addr.2013.08.012

Conflict of Interest Statement: Raymond M. Schiffelers is the CSO of Excytex, a company developing tools for extracellular vesicle research. The other co-authors declare that the research was conducted in the absence of any commercial or financial relationships that could be construed as a potential conflict of interest.

Received: 16 September 2014; accepted: 12 November 2014; published online: 03 December 2014.
Citation: De Jong OG, Van Balkom BWM, Schiffelers RM, Bouten CVC and Verhaar MC (2014) Extracellular vesicles: potential roles in regenerative medicine. Front. Immunol. 5:608. doi: 10.3389/fimmu.2014.00608

This article was submitted to Immunotherapies and Vaccines, a section of the journal Frontiers in Immunology.

Copyright (C) 2014 De Jong, Van Balkom, Schiffelers, Bouten and Verhaar. This is an open-access article distributed under the terms of the Creative Commons Attribution License (CC BY). The use, distribution or reproduction in other forums is permitted, provided the original author(s) or licensor are credited and that the original publication in this journal is cited, in accordance with accepted academic practice. No use, distribution or reproduction is permitted which does not comply with these terms. 